\title{
PELATIHAN PEMBUATAN POMPA TANPA MOTOR (HYDRAULIC RAM PUMP) UNTUK IRIGASI PERTANIAN MASYARAKAT PEKON TIGA JAYA KECAMATAN SEKINCAU LAMPUNG BARAT
}

\author{
Jorfri Boike Sinaga, M Dyan Susila, Hadi Prayitno, Sugiman \\ Jurusan Teknik Mesin, Fakultas Teknik, Universitas Lampung, Bandar Lampung \\ Jl. Prof. Sumantri Brojonegoro No.1 Bandar Lampung 35145 \\ Penulis Korespodensi : jorfri6@yahoo.com
}

\begin{abstract}
Abstrak
Pada makalah ini diberikan kegiatan pelatihan pembuatan pompa tanpa motor (hydraulic ram pump) kepada masyarakat petani Pekon Tiga Jaya, Kecamatan Sekincau. Materi pelatihan yang diberikan secara teori dan praktek yaitu tentang prinsip kerja pompa tanpa motor, pemilihan bahan dan pembuatan pompa tanpa motor (hydram pump), pemasangan dan pengoperasian pompa di lapangan, dan perawatan pompa ini. Berdasarkan kegiatan pelatihan yang dilakukan, dapat dlihat bahwa antusias masyarakat mengikuti kegiatan ini sangat baik untuk memperoleh pemahaman pembuatan pompa tanpa motor (hydraulic ram pump). Hal ini terbukti dengan sikap masyarakat yang serius dan banyak mengajukan pertanyaan saat pelaksanaan pemberian materi teori dan praktek tentang pembuatan pompa tanpa motor (hydram pump). Hasil kegiatan ini juga meningkatkan keinginan masyarakat untuk mengaplikasikan penggunaan pompa ini dalam membantu irigasi pertanian mereka dengan menggunakan dana desa, dengan tetap meminta bantuan bimbingan dari tim pelaksana dari Fakultas Teknik Universitas Lampung.
\end{abstract}

Kata kunci: Pompa tanpa Motor, Hydram Pump, Irigasi, Pertanian

\section{Pendahuluan}

Lahan pertanian yang dijadikan sawah di propinsi Lampung umumnya masih banyak belum mendapat irigasi seperti yang terdapat di Pekon Tiga Jaya, Kecamatan Sekincau. Masyarakat Pekon ini umumnya mengolah lahan pertanian kopi dan sayursayuran, dan dalam mengolah lahan pertanian tersebut hanya bergantung pada curah hujan yang turun. Sehingga areal pertanian di tempat ini tidak dapat ditanami pada musim kemarau karena mengalami kekeringan yang mengakibatkan penurunan produksi tanaman.

Di sekitar areal pertanian ini ada terdapat aliran Kali Fila, namun aliran sungai ini tidak dapat dialirkan langsung ke areal pertanian karena aliran Kali Fila ini terdapat dibagian bawah permukaan areal pertanian sehingga diperlukan pompa untuk megalirkan air Kali Fila tersebut ke areal pertanian petani atau dengan mnengangkat air dari sumber aliran ke areal pertanian. Namun hal ini cukup memberatkan para petani karena tidak memiliki dana yang cukup untuk biaya energi listrik atau bahan bakar untuk pengoperasian pompa.
Hal inilah yang mendorong tim pelaksana untuk melakukan kegiatan pengabdian kepada masyarakat petani di Pekon Tiga Jaya dengan topik pelatihan pembuatan pompa tanpa motor (hydraulic ram pump) untuk sistem irigasi, sehingga nantinya akan membantu mengairi sawah para petani yang nantinya juga akan meningkatkan produksi padi sawah mereka. Dengan penggunaan pompa tanpa motor ini petani tidak perlu mengeluarkan biaya listrik maupun bahan bakar untuk pengoperasiannya, karena pompa tanpa motor ini dapat bekerja secara otomatis tanpa membutuhkan energi bahan bakar ataupun energi listrik tetapi menggunakan aliran Kali Fila itu sendiri. Juga di dalam pengoperasiannya pompa tanpa motor ini hanya membutuhkan sedikit perawatan, karena tidak ada bagian yang bergesekan sehingga penggunaan oil secara rutin untuk perawatan tidak diperlukan seperti penggunaan pompa motor diesel. 


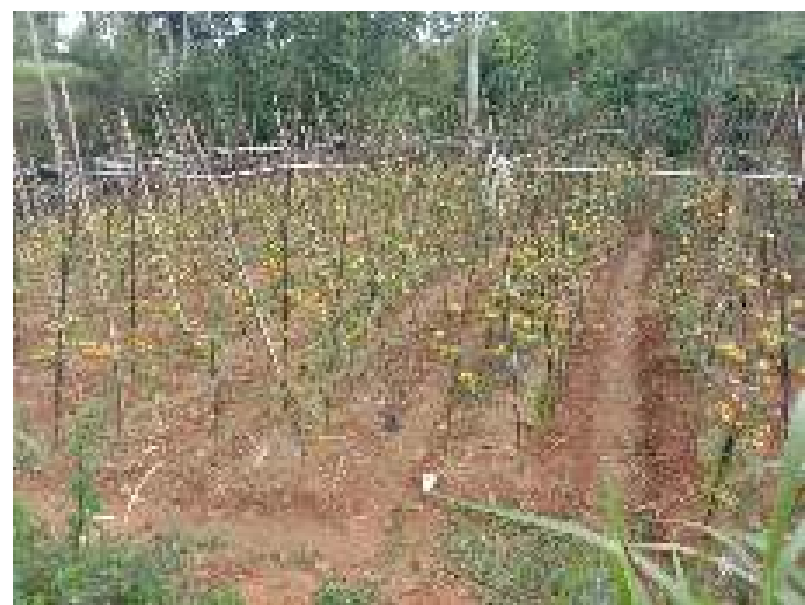

Gambar 1. Kondisi lahan pertanian masyarakat di Pekon Tiga Jaya.

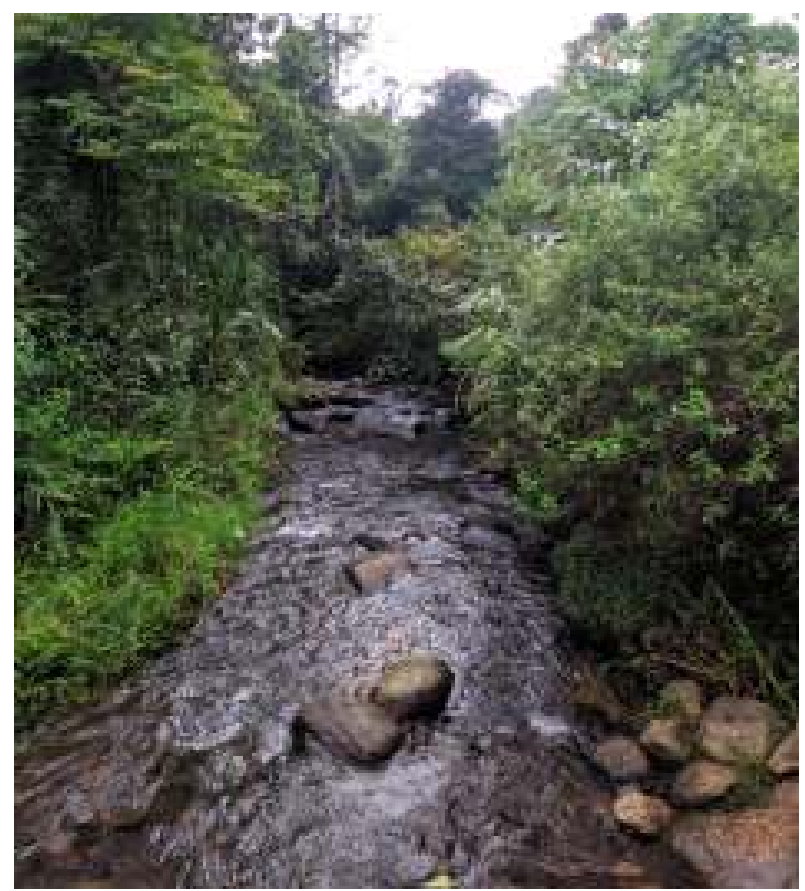

Gambar 2. Aliran Kali Fila yang terdapat di sekitar areal pertanian masyarakat Pekon Tiga Jaya.

Gambar 3 menunjukkan diagram seluruh komponen sistem pompa hydraulic ram pump. Pompa hydraulic ram pump adalah suatu peralatan yang unik dimana peralatan ini menggunakan energi dari aliran air yang memiliki ketinggian jatuh rendah (H) sebagai energi suplai untuk memompa sebagian air ke tempat yang jauh lebih tinggi dari head sumber air (h). Aliran air yang kontinu mengakibatkan pengeoperasian pompa ini juga kontinu dengan tidak menggunakan sumber energi lain (Taye, 1999).

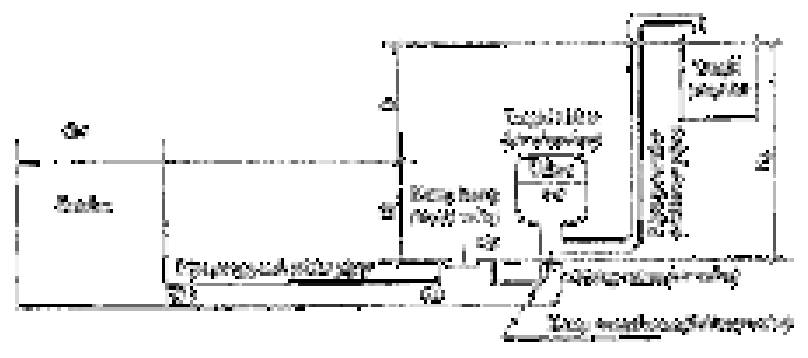

Gambar 3. Instalasi pompa hydraulic ram pump

Pompa hydraulic ram pump adalah satuan yang sederhana secara struktur, terdiri atas dua bagian yang bergerak yaitu: katup pembuangan (waste valve), dan katup pengeluaran (delivery valve). Unit ini juga terdiri atas tangki penyimpan udara (air chamber) dan katup udara masuk (snifter valve). Pengoperasian pompa hydraulic ram pump adalah intermitent akibat siklus pembukaan dan penutupan katup buang dan pengeluaran.

Sebagaimana ditunjukkan sebelumnya, suatu hydram memanfaatkan penutupan aliran yang tibatiba di dalam pipa untuk menghasilkan tekanan surge yang tinggi yang dikenal sebagai water hammer (David dan Edward, 1988). Jika aliran di dalam pipa yang tidak elastis diberhentikan tibatiba, kenaikan tekanan secara teoritik dapat ditentukan dengan menggunakan persamaan di bawah ini.

$$
\Delta \mathrm{H}=\frac{\mathrm{V} \times \mathrm{C}}{\mathrm{g}}
$$

Dimana $\Delta \mathrm{H}$ adalah kenaikan tekanan $(\mathrm{m}), \mathrm{V}$ adalah kecepatan fluida di dalam pipa ( $\mathrm{m} / \mathrm{det}), \mathrm{C}$ adalah kecepatan gelombang suara di dalam fluida $(\mathrm{m} / \mathrm{det})$, dan $\mathrm{g}$ adalah percepatan akibat gravitasi bumi $\left(\mathrm{m} / \mathrm{det}^{2}\right)$.

Persamaan 1 memberikan tekanan maksimum yang mungkin dapat dtimbulkan. Kenaikan tekanan sebenarnya akan lebih rendah dari nilai yang diberikan Persamaan 1, karena semua pipa memiliki nilai elastisitas dan tidak mungkin untuk menutup aliran di dalam pipa dengan seketika. Karena head (H) yang dihasilkan seperti pada Gambar 2, air mengalami percepatan di dalam pipa suplai (drive pipe) dan keluar melalui katup buang (waste valve). Percepatan ini diberikan oleh Persamaan 2 (Fox dan McDonald, 1995). 


$$
H-f \frac{L}{D} \frac{V^{2}}{2 g}-\sum k \frac{V^{2}}{2 g}=\frac{L}{g} \frac{d V}{d t}
$$

Dimana $\mathrm{H}$ adalah head sumber $(\mathrm{m}), \mathrm{f} \frac{\mathrm{L}}{\mathrm{D}} \frac{\mathrm{V}^{2}}{2 \mathrm{~g}}$ adalah kerugian head di dalam pipa akibat gesekan (m), f adalah faktor gesekan (Rumus Darcy-Weibach), $\sum \mathrm{k} \frac{\mathrm{V}^{2}}{2 \mathrm{~g}}$ adalah jumlah seluruh kerugian head minor $\square(\mathrm{m})$, k adalah suatu faktor untuk pengecilan atau pembesaran saluran, L adalah panjang pipa suplai (m), D adalah diameter pipa suplai (m), $\mathrm{V}$ adalah kecepatan aliran di dalam pipa $(\mathrm{m} / \mathrm{det})$, $\mathrm{t}$ adalah waktu (det)

Akhirnya aliran ini akan memiliki kecepatan yang cukup untuk memulai menutup katup buang (waste valve). Hal ini terjadi bila gaya geseran dan tekanan di dalam air sama dengan berat katup pembuangan. Gaya geseran dihitung dengan menggunakan persamaan berikut ini:

$$
F_{d}=C_{d} \times A v \times \rho \times \frac{V^{2}}{2 g}
$$

Dimana $F_{d}$ adalah gaya geseran yang terjadi pada katup pembuangan $(\mathrm{N}), \mathrm{A}_{\mathrm{V}}$ adalah luas penampang katup pembuangan $\left(\mathrm{m}^{2}\right), \rho_{\mathrm{w}}$ adalah massa jenis air $=$ $1000 \mathrm{~kg} / \mathrm{m}^{3}, \mathrm{C}_{\mathrm{d}}$ adalah koefisien geseran katup pembuangan. Koefisien geseran $\mathrm{C}_{\mathrm{d}}$ tergantung pada bilangan Reynolds aliran dan bentuk objek. Untuk benda sirkular, $\mathrm{C}_{\mathrm{d}}=1.12$ (Fox dan Mc. Donald, 1995).

Beberapa parameter yang berhubungan dengan perancangan pompa hydraulic ram pump. Parameter-parameter ini adalah (Tessema, 2000): panjang pipa suplai (L), diameter pipa suplai (D) dan ketebalan pipa suplai, head sumber $(\mathrm{H})$, head penyaluran (h), berat katup buang (W), langkah pemompaan (S), luas orifice yang membuka katup $\left(\mathrm{A}_{0}\right)$, luas penampang katup buang $\left(\mathrm{A}_{\mathrm{V}}\right)$, dan ukuran ruang tabung udara.

Pipa suplai adalah suatu komponen yang penting dari suatu instalasi pompa hydram. Pipa suplai harus dapat menahan tekanan yang tinggi yang diakibatkan oleh penutupan katup pembuangan. Beberapa persamaan emperik untuk menentukan panjang pipa suplai (L) adalah (IDRC, 1986):

$$
\mathrm{L}=150<\mathrm{L} / \mathrm{D}<1000
$$

Tangki udara direkomendasikan kira-kira 100 kali volume air yang akan dipompakan per siklus.
Berbagai percobaan dengan berbagai ukuran menunjukkan bahwa ukuran katup udara tidak mempunyai pengaruh pada pengoperasian pompa hydram. Lubang kecil dengan diameter lebih kecil dari $1 \mathrm{~mm}$ dapat digunakan. Luas penampang aliran $\left(\mathrm{A}_{0}\right)$ yang melalui katup pembuangan harus sama atau melebihi luas penampang pipa suplai untuk mencegah chocking aliran. Direkomendasikan luas penampang katup pipa penyalur $1.45 \mathrm{~cm}^{2}$ untuk tiap liter air yang akan dipompakan.

\section{Metode Pelaksanaan}

Metode pelaksanaan kegiatan ini dilakukan dengan berbagai tahapan yaitu:

a. Tahap persiapan

Persiapan ini difokuskan dengan penyiapan bahanbahan dan peralatan untuk pembuatan model pompa tanpa motor (hydram pump) dan pembuatan modul yang digunakan, serta melakukan koordinasi dengan ketua kelompok tani Putra Mandiri untuk melakukan pelatihan. Peralatan yang digunakan dalam kegiatan ini adalah komputer, perangkat lunak untuk melakukan simulasi aliran pompa tanpa motor (hydram pump), model dan bahan-bahan yang digunakan untuk pembuatan pompa tanpa motor (hydram pump) seperti pipa PVC, pipa galvanis, katup satu arah (check valve), dan katup impuls.

b. Pelaksanaan Pelatihan

Pelatihan ini dilakukan dengan memberikan ceramah dan diskusi serta praktek. Materi-materi pelatihan yang diberikan yaitu tentang prinsip kerja pompa tanpa motor (hydram pump), pemilihan bahan dan pembuatan pompa tanpa motor (hydram pump), penentuan head sumber dan kapasitas air yang dipompakan untuk mengetahui ukuran-ukuran komponen pompa hydram, pemasangan dan pengoperasian pompa di lapangan, dan perawatan pompa. Materi praktek diberikan di lokasi tempat pemasangan pompa tanpa motor dengan memanfaatkan aliran air Kali Fila.

c. Evaluasi

Evaluasi yang dilakukan terhadap kegiatan ini meliputi evaluasi awal yang dilakukan sebelum kegiatan ini dilaksanakan dengan melakukan pretest dan evaluasi akhir setelah kegiatan ini dilakukan. Evaluasi yang dilakukan meliputi pemahaman penduduk tentang prinsip kerja, pemilihan bahan, pengoperasian dan perawatan pompa tanpa motor (hydram pump). 


\section{Hasil dan Pembahasan}

Kegiatan pelatihan kepada masyarakat ini didukung oleh kelompok tani Putra Mandiri, dimana pelaksanaan teori kegiatan ini dilaksanakan di rumah ketua kelompok tani Putra Mandiri. Materi yang diberikan yaitu:

a. Prinsip kerja pompa tanpa motor (hydram pump) dan kegunaannya.

b. Pembuatan pompa hydram pump

c. Perkiraan biaya pembuatan hydram pump

d. Pengoperasian dan pemasangan pompa hydram pump di lapangan.

e. Perawatan pompa hydram pump.

Sementara kegitan praktik pemasangan, pengoperasian, dan perawatan dilakukan di areal pertanian masyarakat dengan memanfaatkan aliran air Kali Fila. Pelatihan ini diikuti oleh peserta yang berasal dari masyarakat dan anggota kelompok tani Putra Mandiri yang ada di Pekon TigaJaya, Kecamatan Sekincau Bandar Lampung.

Parameter-parameter pompa tanpa motor yang digunakan ditentukan dengan menggunakan metode perhitungan yang digunakan Sinaga dkk. (2010). Berdasarkan metode perhitungan yang telah dilakukan sebelumnya dengan menggunakan head sumber 1,5 m, ukuran parameter-parameter model pompa tanpa motor yang digunakan untuk pelaksanaan kegiatan ini dapat dilihat dalam Tabel 1 (Sinaga dkk., 2018).

Tabel 1. Spesifikasi pompa tanpa motor (hydram pump).

\begin{tabular}{|c|c|}
\hline Tinggi Head sumber & $: 1,5 \mathrm{~m}$ \\
\hline Volume Tabung udara & $: \quad 3.285 \mathrm{~cm}^{3}$ \\
\hline Diameter pipa suplai & : 2 in. \\
\hline Panjang pipa suplai & $: 11,3 \mathrm{~m}$ \\
\hline Diameter pipa penyalur & : $5 / 8$ in. \\
\hline Diameter katup buang & $: 5,4 \mathrm{~cm}$ \\
\hline Berat katup buang & : $320 \mathrm{gr}$ \\
\hline Debit air yang dipompakan & $: \quad 3,947 \mathrm{Lit} / \mathrm{mer}$ \\
\hline
\end{tabular}

Evaluasi juga diberikan kepada peserta, dimana tes awal dan tes akhir dirancang untuk mengetahui secara jelas tingkat kemampuan yang dicapai oleh masing-masing peserta. Pertanyaanpertanyaan yang diberikan pada kuisioner terdiri dari 10 pertanyaan. Semua pertanyaan yang diberikan tersebut terdiri dari 5 materi pokok yaitu: pengetahuan tentang dasar-dasar prinsip kerja pompa hydram pump, pengetahuan tentang bahan pembuatan hydram pump, pengetahuan tentang proses pembuatan hydram pump, pengetahuan tentang pemasangan dan pengoperasian hydram pump, dan pengetahuan tentang unjuk kerja dan perawatan pompa hydram pump.

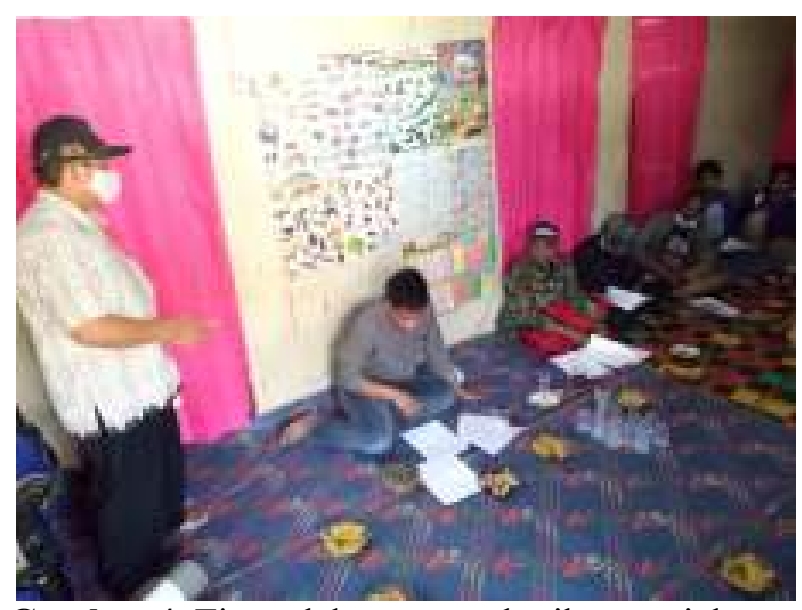

Gambar 4. Tim pelaksana memberikan penjelasan secara teori prinsip kerja dan pembuatan komponen-komponen hydram pump.

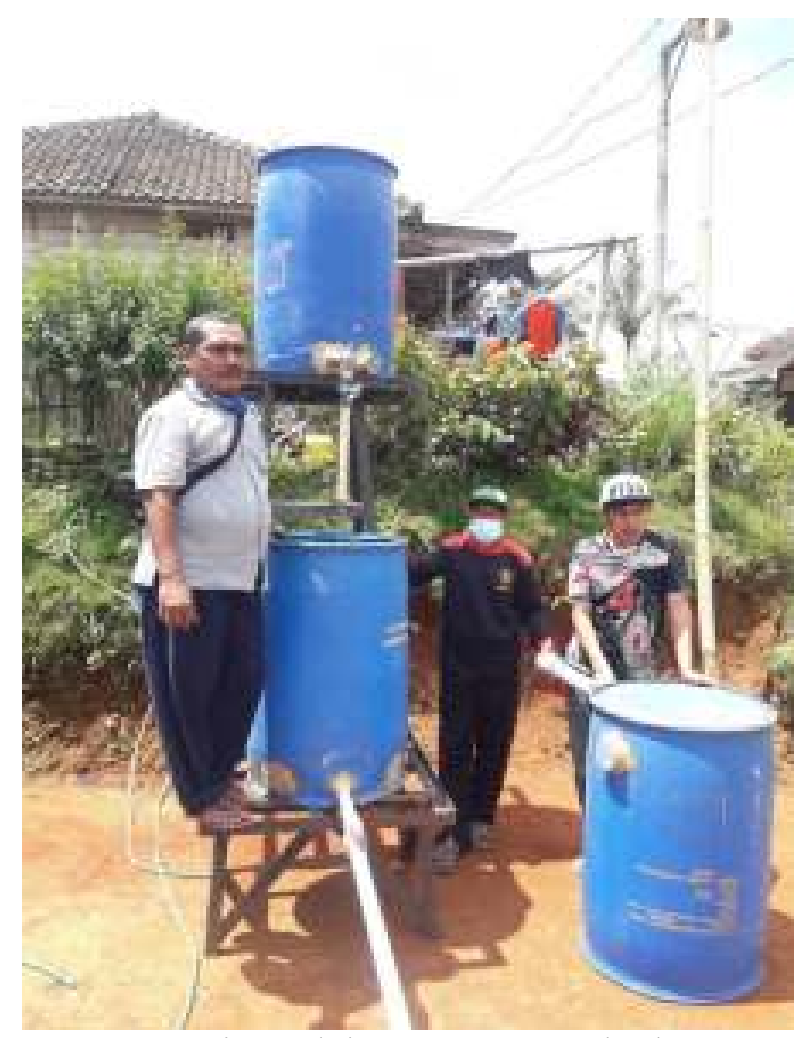

Gambar 5. Tim pelaksana mempersiapkan dudukan dan drum sebagai sumber air saat pemberian materi secara praktek. 


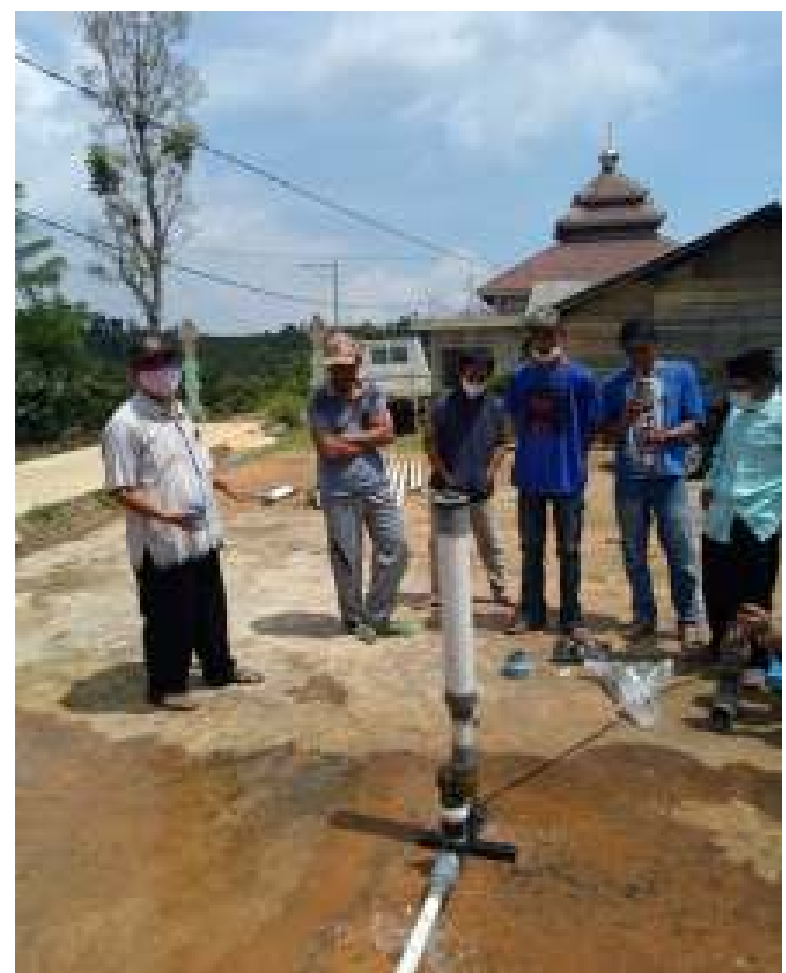

Gambar 6. Tim pelaksana sedang memberikan penjelasan pembuatan dan pemasangan komponen-komponen hydram pump.

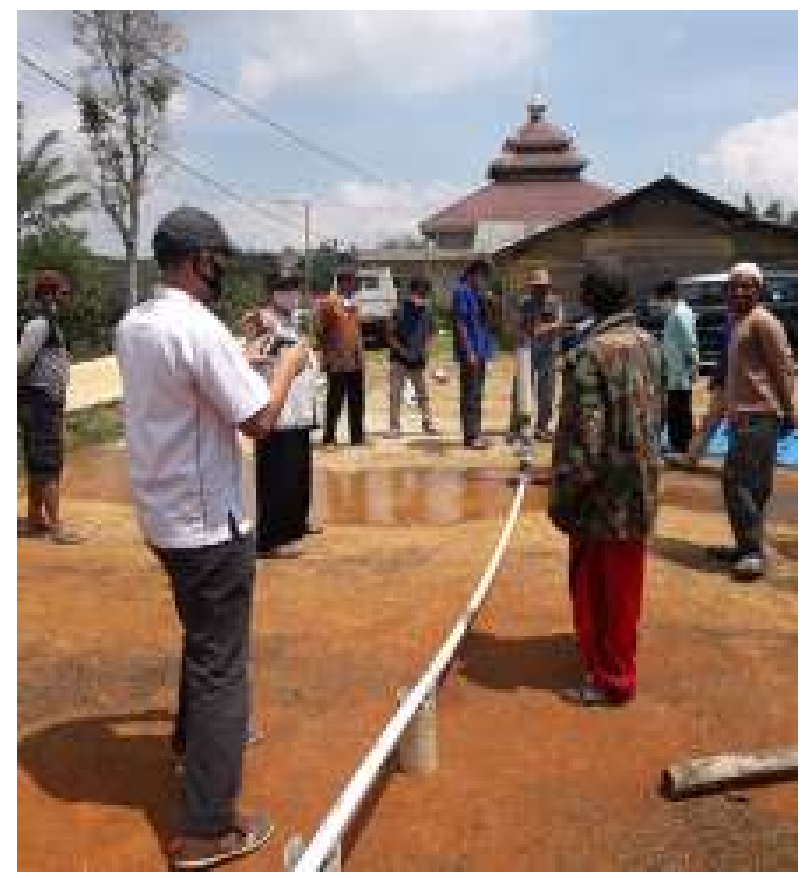

Gambar 7. Tim pelaksana sedang melakukan demonstrasi pengoperasian di lapangan.
Berdasarkan kegiatan yang dilakukan, dapat dilihat bahwa antusias masyarakat untuk mengikuti kegiatan ini sangat tinggi. Hal ini terbukti dengan sikap masyarakat yang serius dan banyak mengajukan pertanyaan saat pelaksanaan pemberian materi teori dan praktek tentang pembuatan, pemasangan, dan perawatan pompa tanpa motor (hydram pump). Karena ini memberikan informasi bagi masyarakat bahwa ada pompa yang dapat bekerja tanpa menggunakan motor diesel atau motor listrik. Dan masyarakat berniat ingin mengaplikasikan penggunaan pompa ini untuk membantu irigasi pertanian mereka, dengan tetap meminta bantuan bimbingan dari tim pelaksana Fakultas Teknik UNILA dalam pembuatan dan pengoperasiannya di lapangan.

Hasil evaluasi yang dilakukan terhadap peserta pelatihan berupa soal-soal yang diberikan sebelum dan sesudah kegiatan ini dilaksanakan dapat dilihat bahwa pengetahuan masyarakat tentang pembuatan, pemasangan, dan perawatan pompa tanpa motor (hydram pump) meningkat, yang awalnya dengan nilai rata-rata 47,67 menjadi 80. Dari hasil diskusi atau tanya jawab yang dilakukan terlihat keinginan beberapa peserta untuk menerapkan langsung pengetahuan yang mereka peroleh ini tidak hanya untuk irigasi pertanian, tapi juga untuk memenuhi kebutuhan air bagi rumah tangga.

\section{Kesimpulan}

Setelah melakukan kegiatan ini, maka dapat ditaraik kesimpulan:

1. Pelaksanaan kegiatan ini berlangsung dengan baik dan antusias masyarakat Pekon Tiga Jaya, Kecamatan Sekincau, Bandar Lampung dalam mengikuti kegiatan pelatihan pembuatan pompa tanpa motor (hydraulic ram pump) ini sangat tinggi.

2. Kegiatan pengabdian kepada masyarakat ini berhasil meningkatkan pengetahuan masyarakat untuk melakukan pemilihan bahan dan pembuatan pompa tanpa motor (hydraulic ram pump) yang sesuai dengan kebutuhan dan melakukan perawatan pompa tersebut.

3. Perlu dilakukan pengembangan programprogram kegiatan pengabdian kepada masyarakat lainnya seperti alat pengering kopi. 


\section{Ucapan Terima Kasih}

Terima kasih disampaikan kepada LPPM UNILA yang telah mendanai keberlangsungan pelaksanaan kegiatan pengabdian kepada masyarakat ini.

\section{Daftar Pustaka}

David, J.P. \& Edward, H.W. (1985). Schaum's Outline of Theory and Problems of Fluid Mechanics and Hydraulics, SI (Metric) Edition, McGraw-Hill Book Company, Singapore.

Fox, R. W., \& Mc Donald, A. T. (1995). Introduction to Fluid Mechanics. John Wiley \& Sons, New York.

IDRC. (1986). Proceedings of a Workshop on Hydraulic Ram Pump (Hydram) Technology. Arusha, Tanzania. International Development Research Center (IDRC).

Sinaga, J. B., A. Suudi, dan Azhar. (2010). Optimasi Rancang Bangun Pompa Tanpa Motor (Hydraulic
Ram Pump) untuk Irigasi Pertanian di Propinsi Lampung. Laporan Tahun Pertama Hibah Kompetitif Penelitian Strategis Nasional, Universitas lampung.

Sinaga, J. B., Supriadi, H., Suudi, A., Simarmata, R., A., dan Sugiman. (2018) Design of Hydraulic Ram Pump To Help The Community Agricultural Irrigation System In TigaJaya, Sekincau Distric, Bandar Lampung. Prosiding Seminar Nasional Tahunan Teknik Mesin (SNTTM). Kupang, Indonesia: Program Studi Teknik Mesin, Fakultas Sains dan Teknik, Universitas Nusa Cendana (Undana).

Taye, T. (1999). Hydraulic Ram Pump, Journal of the Ethiopian Society of Mechanical Engineers, Vol. II, No. 1. 